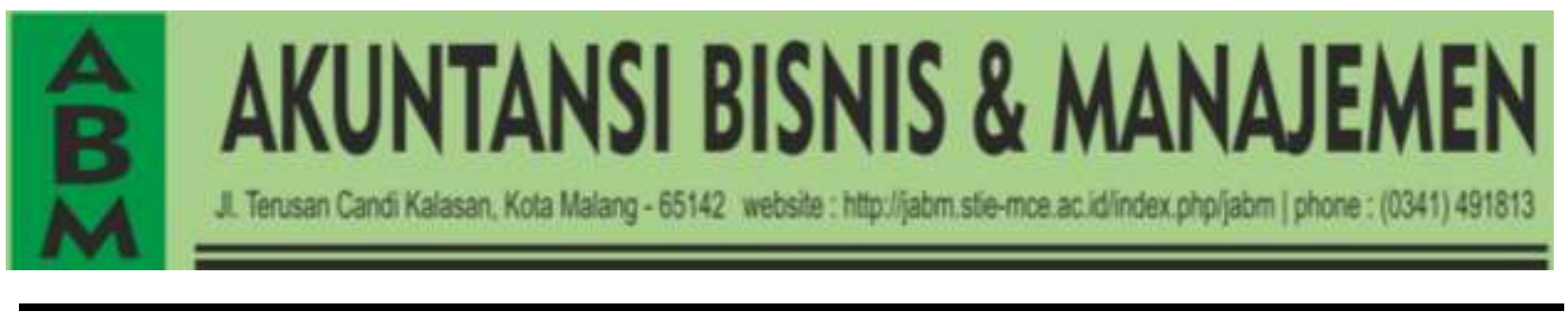

\title{
PENDIDIKAN PENGELOLAAN KEUANGAN KELUARGA, GAYA HIDUP, PEMBELAJARAN SERTA PENGARUHNYA TERHADAP LITERASI KEUANGAN
}

\author{
Atika Syuliswati \\ Politeknik Negeri Malang \\ Jalan Soekarno Hatta No. 9 Kota Malang - 65141, Jawa Timur \\ E-Mail:atikasyuliswati@gmail.com
}

\begin{tabular}{l} 
Akuntansi Bisnis dan \\
Manajemen (ABM), \\
\hline Volume 27 \\
Nomor 1 \\
Halaman 53-64 \\
Bulan April, Tahun 2020 \\
ISSN 0854-4190 \\
E-ISSN 2685-3965
\end{tabular}

Akuntansi Bisnis dan

Volume 27

Nomor 1

Halaman 53-64

Bulan April, Tahun 2020

ISSN 0854-4190

E-ISSN 2685-3965

Informasi Artikel

Tanggal Masuk:

9 Januari 2020

Tanggal Revisi:

15 Februari 2020

Tanggal Diterima:

28 Maret 2020

\begin{abstract}
The purpose of this study was to examine the effect of family financial management education, life style, and learning in higher education to financial literacy simultaneously and partially to students of the Accounting Department of State Polytechnic Malang. This research is a quantitative research and a sample consist of 142 students of the Accounting Department of State Polytechnic Malang. The method used is survey method using questionnaire given to the respondent to be answered. Question in questionnaire using likert scale. Data analysis method used in this research is multiple linear regression analysis. The results showed simultaneously and partially family financial management education, life style, and learning in higher education have significant effect on financial literacy.
\end{abstract}

Keywords: family financial management education; life style; learning in higher education; financial literacy

\begin{abstract}
Abstrak
Tujuan penelitian ini adalah untuk mengetahui pengaruh pendidikar pengelolaan keuangan keluarga, gaya hidup, dan pembelajaran di perguruar tinggi terhadap literasi keuangan secara parsial dan simultan pad. mahasiswa di Jurusan Akuntansi Politeknik Negeri Malang. Penelitian in adalah penelitian kuantitatif dan sampel berjumlah 142 mahasiswa Jurusar Akuntansi Politeknik Negeri Malang. Metode yang digunakan adalah metod. survei dengan menggunakan kuisioner yang diberikan kepada responder untuk dijawab. Pertanyaan dalam kuisioner menggunakan skala likert Metode analisis data yang digunakan dalam penelitian ini adalah Regres Linear Berganda. Hasil penelitian menunjukkan secara simultan dan parsia pendidikan pengelolaan keuangan keluarga, gaya hidup, dan pembelajaran d perguruan tinggi berpengaruh signifikan terhadap literasi keuangan.

Kata Kunci: pendidikan pengelolaan keuangan keluarga, gaya hidup, dar pembelajaran di perguruan tinggi, literasi keuangan
\end{abstract}




\section{PENDAHULUAN}

Mahasiswa sebagai generasi muda akan menghadapi kompleksitas yang semakin meningkat dalam produk, jasa, dan pasar keuangan mereka cenderung harus menanggung risiko keuangan lebih tinggi dibandingkan orang tua mereka. Mahasiswa umumnya memiliki kebebasan yang lebih besar untuk membuat keputusan pribadi, termasuk dalam hal keuangan. Banyak mahasiswa belajar dari trial and error, namun hal itu belum mampu menjadikan mereka menjadi pelaku ekonomi yang cerdas dalam kehidupan saat ini.

Jorgensen (2007) menyebutkan bahwa tingkat pengetahuan keuangan yang tinggi berkorelasi positif terhadap tingkat penghasilan dan tabungan yang lebih tinggi. Dengan memiliki literasi keuangan mahasiswa mampu membuat keputusan untuk kehidupannya dan menerima tanggung jawab atas tindakan mereka sendiri. Pendidikan sangat berperan penting dalam pembentukan literasi keuangan baik pendidikan informal di lingkungan keluarga maupun pendidikan formal di lingkungan perguruan tinggi. Di dalam lingkungan keluarga, tingkat literasi keuangan ditentukan oleh peran orang tua dalam memberikan dukungan berupa pendidikan keuangan dalam keluarga. Gaya hidup juga berperan dalam pembentukan literasi keuangan. Gaya hidup adalah kebiasaan hidup seseorang dalam mengalokasikan uang dan waktunya yang dilihat dari pola konsumsi, gaya berpakaian, dan pola rekreasi. Pembelajaran di perguruan tinggi sangat berperan penting dalam proses pembentukan literasi keuangan mahasiswa. Pembelajaran yang efektif dan efisien akan membantu mahasiswa memiliki kemampuan memahami, menilai, dan bertindak dalam kepentingan keuangan mereka.

Chen dan Volpe (1998) dalam penelitiannya menemukan bahwa mahasiswa yang memiliki tingkat literasi finansial rendah cenderung berpendapat negatif tentang keuangan dan membuat keputusan yang salah. Dengan memiliki literasi finansial, mahasiswa mampu membuat keputusan untuk kehidupan mereka dan menerima tanggung jawab atas tindakan mereka sendiri. Jorgensen (2007) menyatakan "Students who reported they learned either some or a lot about managing their money from parents had higher financial knowledge, attitude, and behavior scores than students who reported learning none or not much about managing their money from their parents." Gutter \& Garrison (2008) dalam penelitiannya menyatakan bahwa pendidikan keuangan berpengaruh positif signifikan terhadap pengetahuan, sikap dan perilaku keuangan. Diperkuat oleh penelitian Lutfi dan Iramani (2008) yang menyatakan bahwa pendidikan manajemen keuangan secara signifikan berpengaruh terhadap literasi finansial.

Menurut Myers (2015:5) status sosial ekonomi orang tua mempunyai pengaruh terhadap tingkah laku dan pengalaman anak-anaknya. Perbedaan tingkat status sosial ekonomi akan berdampak pada munculnya perbedaan persepsi atas suatu obyek fisik atau obyek perilaku, yang pada akhirnya membentuk sikap yang berbeda pula. Persepsi positif terhadap karakteristik atau sifat obyek akan membentuk sikap positif pula. Hasil penelitian Lusardi et. al., (2010) "parent education, parental wealth, and sophistication of the family finances significantly influence the financial literacy of children." Fowdar (2007) dalam penelitiannya menyatakan bahwa tingkat literasi seseorang dipengaruhi oleh tingkat pekerjaan orang tua. Selanjutnya penelitian Gutter \& Garrison (2008) menyatakan bahwa mahasiswa yang mempunyai status sosial ekonomi yang 
tinggi juga mempunyai tingkat pengetahuan, sikap, dan perilaku keuangan yang tinggi.

Hasil pendidikan yang diperoleh anak dalam keluarga akan menentukan pendidikan anak selanjutnya, baik di sekolah maupun di masyarakat (Widayati, 2012). Keluarga merupakan lingkungan pertama dan utama sebagai pembentuk keterampilan hidup pada anak. Orang tua adalah agen sosialisasi utama dalam proses dimana anak belajar bagaimana anak memfungsikan diri mereka dalam pasar sebagai konsumen dan pengelolaan uang. Dengan memberikan pendidikan pengelolaan keuangan maka ada beberapa hal yang positif terkait dengan membelanjakan, menabung, maupun menginvestasikan uang dengan benar (Widayati, 2012).

Selanjutnya menurut pernyataan dari Wahyono (2001) menyatakan bahwa proses pendidikan keuangan di keluarga, seperti halnya untuk aspek-aspek lain dan biasanya tidak terjadwal sehingga berlangsung terjadi setiap saat dan bersifat insidental, maka proses keteladanan dan sikap keseharian orang tua serta intensitas komunikasi antara anak dan orang tua dalam kehidupan keluarga memiliki peran penting bagi pendidikan keuangan anak.

Dari uraian diatas masih terdapat perbedaan variabel yang digunakan dalam menganalisis faktor-faktor yang mempengaruhi literasi keuangan. Berdasarkan konsep tersebut maka tujuan penelitian adalah untuk menganalisis pengaruh pendidikan pengelolaan keuangan keluarga, gaya hidup, dan pembelajaran di perguruan tinggi secara simultan dan parsial terhadap literasi keuangan mahasiswa jurusan Akuntansi Politeknik Negeri Malang.

\section{KAJIAN PUSTAKA}

\section{Pendidikan Pengelolaan Keuangan Keluarga}

Pendidikan pengelolaan keuangan di lingkungan keluarga dititik beratkan pada pemahaman tentang nilai uang dan penanaman sikap serta perilaku anak untuk dapat mengatur pemanfaatan uang. Berdasarkan pendapat dai ahli bahwa untuk memiliki keterampilan mengelola keuangan dengan baik, paling tidak anak harus dilatih dalam hal menabung, melakukan pembayaran secara mandiri atas kebutuhan-kebutuhan tambahan mereka, mengelola uang saku, melakukan pekerjaan-pekerjaan rumah tertentu untuk mendapatkan uang saku tambahan, mencari pekerjaan ringan di luar rumah, berderma dan berinvestasi (Mundir, 2018). Dalam penelitian Jorgensen (2007) ditemukan "students who were financially influenced by their parents had higher financial knowledge, attitude, and behavior scores." Cude et. al. (2006) menyatakan bahwa orang tua memainkan peranan yang sangat penting dalam proses sosialisasi keuangan anak-anak mereka.

\section{Gaya Hidup}

Gaya hidup adalah kebiasaan hidup seseorang dalam mengalokasikan uang dan waktunya yang dilihat dari pola konsumsi, gaya berpakaian, dan pola rekreasi. Gaya hidup merupakan pola hidup seseorang di dunia yang terungkap pada aktivitas, minat, dan opininya (Sumarwan, 2014:45). Jika dikaitkan dengan literasi keuangan, gaya hidup sangat berpengaruh dalam proses keputusan konsumen. Gaya hidup merujuk pada bagaimana seseorang hidup, bagaimana mereka membelanjakan 
uangnya, bagaimana mereka mengalokasikan waktu mereka dan merupakan manifestasi dari konsep diri atau citra diri, atau keseluruhan citra yang dimiliki oleh dirinya sendiri. Gaya hidup menurut Kottler \& Amstrong (2017:27) adalah pola hidup seseorang dalam kehidupan sehari-hari yang dinyatakan dalam kegiatan, minat, dan pendapat yang bersangkutan.

\section{Pembelajaran di Perguruan Tinggi}

Pembelajaran hakikatnya adalah usaha sadar guru untuk mendidik siswanya (mengarahkan interaksi siswa dengan sumber belajar lainnya) dalam rangka mencapai tujuan yang diharapkan (Trianto, 2015:17). Pembelajaran di perguruan tinggi sangat berperan penting dalam proses pembentukan literasi keuangan mahasiswa. Melalui kombinasi berbagai metode pengajaran, media dan sumber belajar yang direncanakan dengan baik dan sesuai dengan kompetensi, diharapkan mampu memberikan bekal kepada mahasiswa untuk memiliki kecakapan di bidang keuangan, sehingga mahasiswa menjadi siap dan mampu menghadapi kehidupan mereka saat ini maupun masa depan yang semakin kompleks (Lutfi dan Iramani, 2008). Adapun penelitian terkait yaitu hasil penelitian Jhonson (2007) menyatakan bahwa pendidikan keuangan memiliki peran yang sangat penting bagi siswa untuk memiliki kemampuan memahami, menilai, dan bertindak dalam kepentingan keuangan mereka. Pendidikan keuangan pada dasarnya bertujuan untuk meningkatkan pengetahuan dan kesadaran keuangan, terbukti bahwa itu bekerja dengan baik di kelas dan di sekolah (Bruhn et al. 2016). Pendidikan keuangan juga memiliki efek positif tidak langsung pada perilaku keuangan, meskipun efek tidak langsung ini kecil sehingga perubahan perilaku keuangan juga harus ditangani secara langsung (Kaiser \& Menkhoff, 2017). Pendidikan keuangan di sekolah sangat penting (Lusardi \& Mitchell, 2007). Selanjutnya Gutter \& Garrison (2008) dalam penelitiannya menyatakan bahwa pendidikan keuangan berpengaruh positif signifikan terhadap pengetahuan dan sikap keuangan. Diperkuat oleh penelitian Lutfi dan Iramani (2008) yang menyatakan bahwa pendidikan manajemen keuangan secara signifikan berpengaruh terhadap literasi finansial.

\section{Literasi Keuangan}

Literasi keuangan dapat diartikan sebagai pengetahuan keuangan, yang memiliki tujuan untuk mencapai kesejahteraan (Lusardi \& Mitchell, 2014). Kapoor (2011) serta Andreou \& Philip (2018) juga menyatakan bahwa diperlukan pengetahuan tentang bagaimana mengelola keuangan serta bagaimana teknik berinvestasi yang nantinya bisa jadi hal yang tidak dapat diabaikan lagi seperti waktu-waktu seperti sebelumsebelumnya. Alat keuangan (financial tools) merupakan bentuk dan bagian yang digunakan dalam memutuskan manajemen keuangan pribadi (contohnya seperti cek, kartu kredit, kartu debit, dan uang tunai).

\section{Model Hipotesis}

Berdasarkan landasan teori, masalah penelitian dan penelitian terdahulu, maka penulis mengembangkan model hipotesis sebagai berikut: 


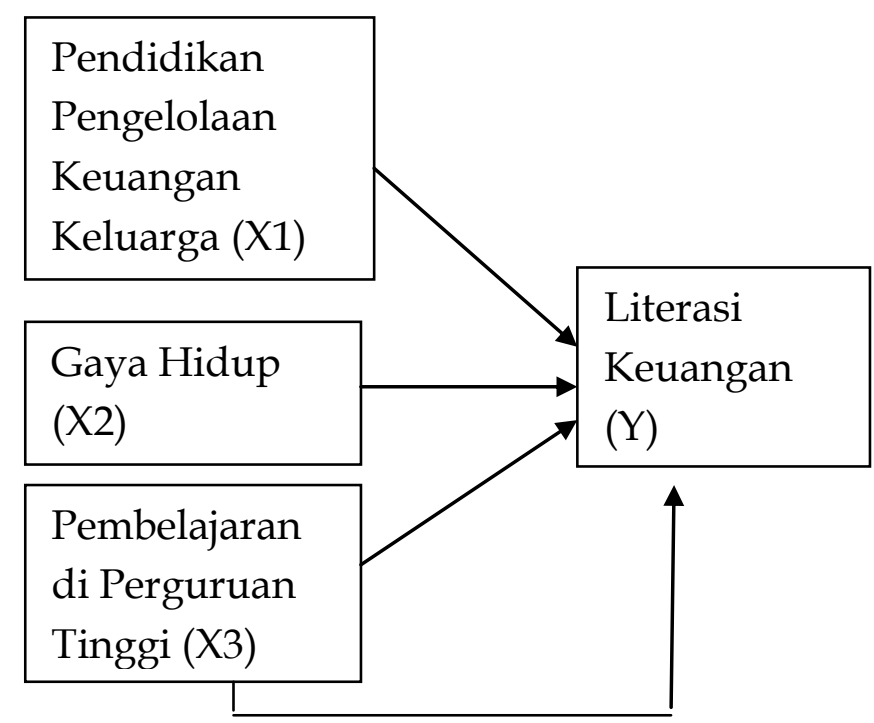

\section{Gambar 1. Model Hipotesis}

\section{Hipotesis Penelitian}

Pendidikan sangat berperan penting dalam pembentukan literasi finansial baik pendidikan informal di lingkungan keluarga maupun pendidikan formal di lingkungan perguruan tinggi. Di dalam lingkungan keluarga, tingkat literasi finansial ditentukan oleh peran orang tua dalam memberikan dukungan berupa pendidikan keuangan dalam keluarga. Pendidikan Pengelolaan Keuangan Keluarga merupakan tempat tumbuh berkembangnya mahasiswa untuk pertama kali. Pembentukan sikap serta penanaman nilai-nilai kehidupan dikeluarga sangat penting. Keluarga menjadi tempat yang dominan dalam proses sosialisasi tentang masalah keuangan. Teori belajar sosial (Jorgensen, 2007) menjelaskan pengaruh lingkungan mahasiswa telah selama bertahun-tahun membentuk mahasiswa menjadi siapa mereka hari ini. Sikap dan nilainilai keuangan mahasiswa tentang uang berasal dari lingkungan rumah mahasiswa. Dalam penelitian Jorgensen (2007) ditemukan "students who were financially influenced by their parents had higher financial knowledge, attitude, and behavior scores." Cude et. al. (2006) menyatakan bahwa orang tua memainkan peranan yang sangat penting dalam proses sosialisasi keuangan anak-anak mereka.

Gaya hidup juga berperan dalam pembentukan literasi finansial. Gaya hidup adalah kebiasaan hidup seseorang dalam mengalokasikan uang dan waktunya yang dilihat dari pola konsumsi, gaya berpakaian, dan pola rekreasi. Gaya hidup menggambarkan perilaku seseorang, yaitu bagaimana ia hidup, menggunakan uangnya, dan memanfaatkan waktu yang dimilikinya. Gaya hidup mencerminkan pola tingkah laku sehari-hari segolongan manusia. Pembelajaran di perguruan tinggi sangat berperan penting dalam proses pembentukan literasi finansial mahasiswa. Pembelajaran yang efektif dan efisien akan membantu mahasiswa memiliki kemampuan memahami, menilai, dan bertindak dalam kepentingan keuangan mereka. penelitian terkait yaitu hasil penelitian Jhonson (2007) menyatakan bahwa pendidikan keuangan memiliki peran yang sangatpenting bagi siswa untuk memiliki kemampuan memahami, menilai, dan bertindak dalam kepentingan keuangan mereka. Selanjutnya Gutter \& Garrison (2008) dalam penelitiannya menyatakan bahwa pendidikan 
keuangan berpengaruh positif signifikan terhadap pengetahuan dan sikap keuangan. Diperkuat oleh penelitian Lutfi dan Iramani (2008) yang menyatakan bahwa pendidikan manajemen keuangan secara signifikan berpengaruh terhadap literasi finansial.

Hipotesis penelitian sebagai berikut:

H1: Terdapat pengaruh pendidikan pengelolaan keuangan keluarga, gaya hidup, dan pembelajaran di perguruan tinggi secara simultan terhadap literasi keuangan mahasiswa jurusan Akuntansi Politeknik Negeri Malang.

H2: Terdapat pengaruh pendidikan pengelolaan keuangan keluarga, gaya hidup, dan pembelajaran di perguruan tinggi secara parsial terhadap literasi keuangan mahasiswa jurusan Akuntansi Politeknik Negeri Malang.

\section{METODE PENELITIAN}

Penelitian ini tergolong sebagai penelitian kuantitatif khususnya deskriptif analitis. Menurut Sugiyono (2017:23) penelitian deskriptif analitis dilakukan untuk mengetahui nilai variabel mandiri, baik satu variabel atau lebih. Dalam penelitian ini, populasi penelitian mengacu pada mahasiswa diploma 4 jurusan akuntansi politeknik negeri malang semester 4 berjumlah 220 mahasiswa. Pengambilan sampel dilakukan dengan teknik probability sampling yaitu proportionate stratified random sampling dengan menggunakan rumus slovin. Besarnya sampel dalam penelitian ini adalah 142 mahasiswa.

Metode yang digunakan adalah metode survei dengan menggunakan kuesioner yang diberikan kepada responden untuk dijawab. Teknik analisis data pada penelitian ini adalah dengan menggunakan analisis regresi linier berganda. Penelitian diuji dengan beberapa uji statistik yang terdiri dari uji kualitas data, uji asumsi klasik, statistik deskriptif, uji statistik untuk pengujian hipotesis.Uji kualitas data meliputi reliabilitas dan validitas. Uji asumsi klasik meliputi normalitas, multikolinearitas, heteroskedastisitas, dan autokorelasi. Pengujian Hipotesis meliputi uji F dan uji t.

Variabel didefinisikan secara operasional agar lebih mudah dicari hubungan antara satu variabel dengan lainnya dan pengukurannya. Definisi operasional dalam penelitian ini dapat dilihat pada tabel 1 ini:

\section{Tabel 1. Definisi Operasional}

\begin{tabular}{|c|c|c|c|}
\hline Variabel & $\begin{array}{c}\text { Definisi } \\
\text { Operasional }\end{array}$ & Indikator & Skala \\
\hline $\begin{array}{l}\text { Pendidikan } \\
\text { Pengelolaan } \\
\text { Keuangan } \\
\text { Keluarga }\end{array}$ & $\begin{array}{l}\text { Pendidikan } \\
\text { dimana anak } \\
\text { belajar } \\
\text { memfungsikan } \\
\text { diri mereka dalam } \\
\text { pasar sebagai } \\
\text { konsumen dan } \\
\text { pengelolaan uang } \\
\text { dalam keluarga. }\end{array}$ & $\begin{array}{l}\text { 1. Keterlibatan orang tua dalam pengambilan } \\
\text { keputusan finansial anak. } \\
\text { 2. Kebiasaan menabung yang diajarkan orang } \\
\text { tua. } \\
\text { 3. Kebiasaan berderma yang diajarkan orang } \\
\text { tua. } \\
\text { 4. Kepercayaan orang tua kepada anak untuk } \\
\text { melakukan pembayaran sendiri. } \\
\text { 5. Diskusi bersama anak mengenai masalah } \\
\text { keuangan. } \\
\text { 6. Komunikasi orang tua mengenai } \\
\text { pembelajaran keuangan. }\end{array}$ & Likert \\
\hline
\end{tabular}




\begin{tabular}{|c|c|c|c|}
\hline Gaya Hidup & $\begin{array}{l}\text { Kebiasaan hidup } \\
\text { seseorang dalam } \\
\text { mengalokasikan } \\
\text { uang dan } \\
\text { waktunya yang } \\
\text { dilihat dari pola } \\
\text { konsumsi, gaya } \\
\text { berpakaian, dan } \\
\text { pola rekreasi. }\end{array}$ & $\begin{array}{l}\text { 1. Penggunaan kendaraan bermotor. } \\
\text { 2. Penggunaan smartphone. } \\
\text { 3. Penggunaan uang saku. } \\
\text { 4. Pembelian pakaian baru. } \\
\text { 5. Pembelian makanan. } \\
\text { 6. Pemilihan tempat makan. } \\
\text { 7. Penggunaan laptop. } \\
\text { 8. Penggunaan paket internet. }\end{array}$ & Likert \\
\hline $\begin{array}{l}\text { Pembelajaran } \\
\text { Di Perguruan } \\
\text { Tinggi }\end{array}$ & $\begin{array}{l}\text { Hasil belajar } \\
\text { seseorang di } \\
\text { perguruan tinggi }\end{array}$ & $\begin{array}{l}\text { 1. Mata kuliah yang dapat menambah literasi } \\
\text { keuangan mahasiswa. } \\
\text { 2. Metode pengajaran yang dapat menambah } \\
\text { pengetahuan mahasiswa mengenai } \\
\text { keuangan. } \\
\text { 3. Keterlibatan kampus dalam } \\
\text { menyelenggarakan seminar keuangan. } \\
\text { 4. Referensi yang disediakan oleh perguruan } \\
\text { tinggi berkaitan dengan literasi keuangan. }\end{array}$ & Likert \\
\hline $\begin{array}{l}\text { Literasi } \\
\text { Keuangan }\end{array}$ & $\begin{array}{l}\text { Tingkat } \\
\text { kemampuan ilmu } \\
\text { pengetahuan yang } \\
\text { dimiliki seseorang } \\
\text { (yang berbeda- } \\
\text { beda) } \\
\text { mempengaruhi } \\
\text { cara seseorang } \\
\text { dalam membuat } \\
\text { keputusan }\end{array}$ & $\begin{array}{l}\text { 1. Membeli barang-barang dengan kredit akan } \\
\text { mengurangi daya beli. } \\
\text { 2. Di masa depan, peningkatan harga barang } \\
\text { akan mengurangi daya beli. } \\
\text { 3. Pemegang kartu kredit dapat menghabiskan } \\
\text { uang tanpa batas. } \\
\text { 4. Tabungan adalah tambahan pendapatan } \\
\text { setelah dikurangi biaya. } \\
\text { 5. Bunga akan mempengaruhi nilai masa } \\
\text { depan tabungan. } \\
\text { 6. Membeli asuransi adalah investasi terbaik. } \\
\text { 7. Bunga tabungan melebihi deposito bunga. } \\
\text { 8. Semua jenis investasi adalah } \\
\text { menguntungkan. }\end{array}$ & Likert \\
\hline
\end{tabular}

\section{HASIL DAN PEMBAHASAN}

Pengujian validitas instrumen dengan bantuan perangkat lunak SPSS, nilai validitas dapat dilihat pada kolom Corrected Item-Total Correlation. Jika nilai pearson correlation yang diperoleh lebih besar daripada angka kritik ( $\mathrm{r}$ hitung $>\mathrm{r}$ tabel) maka instrumen tersebut dikatakan valid. Angka kritik pada penelitian ini adalah N-2 = 30-2 $=28$ dengan taraf signifikan $5 \%$ atau $\mathrm{df}=(a, n-2)$ maka angka kritik untuk uji validitas pada penelitian ini adalah 0,374 . Berdasarkan pengujian validitas instrumen, nilai Corrected Item-Total Correlation bernilai positif dan di atas nilai $\mathrm{r}$ tabel $(0,374)$ yang artinya semua butir pertanyaan dapat dikatakan valid.

Untuk mengetahui apakah kuesioner tersebut telah reliabel, maka dilakukanlah pengujian reliabilitas kuesioner dengan bantuan komputer program SPSS. Uji reliabilitas dilakukan untuk menunjukkan sejauh mana suatu alat pengukur dapat dipercaya. Secara umum suatu instrumen dikatakan bagus jika memiliki koefisien Cronbach's alpha sebesar $>0,6$. Nilai Croncbach's Alpha untuk variabel literasi keuangan $(\mathrm{Y})$, Pendidikan pengelolaan keuangan keluarga $(\mathrm{X} 1)$, gaya hidup $(\mathrm{X} 2)$, pembelajaran di 
perguruan tinggi (X3) lebih besar dari 0,6 (Croncbach's Alpha > 0,6), maka dapat disimpulkan bahwa instrumen penelitian tersebut realibel. Hasil uji asumsi klasik menunjukkan data terdistribusi dengan normal, tidak terjadi multikolinearitas, tidak terjadi heteroskedastisitas, dan bebas autokorelasi.

Pengaruh variabel independen secara simultan terhadap variabel dependen dianalisis dengan menggunakan uji $\mathrm{F}$, yaitu dengan memperhatikan signifikansi nilai $\mathrm{F}$ pada output perhitungan dengan tingkat alpha 5\%. Pada hasil uji regresi dalam penelitian ini, diketahui nilai uji F sebesar 35.759 dengan signifikansi 0,000. Dimana disyaratkan nilai signifikansi F lebih kecil dari 5\%. Dengan demikian dapat disimpulkan bahwa semua variabel independen dalam penelitian ini secara bersamasama (simultan) berpengaruh terhadap literasi keuangan (Y). Hasil pengujian uji $\mathrm{F}$ pada penelitian ini dapat dilihat pada tabel 2:

Tabel 2. ANOVA

\begin{tabular}{rrrllll}
\hline Model & & Sum of squares & Df & Mean Square & F & Sig. \\
\hline 1 & Regression & 2760.998 & 4 & 969.887 & 35.759 & .000 \\
& Residual & 2870.789 & 138 & 28.325 & & \\
& Total & 5631.787 & 142 & & & \\
\hline
\end{tabular}

Nilai $\mathrm{t}$ hitung dari hasil regresi tersebut untuk mengetahui pengaruh variabel independen secara parsial terhadap variabel dependen dengan tingkat kepercayaan 95\% atau pada alpha 5\%. Pada penelitian ini uji t digunakan untuk menguji apakah hipotesis yang diajukan dalam penelitian ini diterima atau tidak dengan mengetahui apakah variabel independen secara individual mempengaruhi variabel dependen. Adapun metode dalam penentuan $t$ tabel menggunakan ketentuan tingkat signifikansi $5 \%$, dengan $\mathrm{df}=\mathrm{n}-\mathrm{k}-1$ (pada penelitian ini $\mathrm{df}=142-4-1=137$ ), sehingga didapat nilai $\mathrm{t}$ tabel sebesar 1,65597. Dari nilai tersebut yang kemudian dibandingkan dengan nilai $\mathrm{t}$ hitung. Hasil uji t hitung untuk variabel X1 sebesar 2,789, variabel X2 sebesar 3,717, dan variabel X3 sebesar 2,035. Sehingga didapatkan hasil pendidikan pengelolaan keuangan keluarga (X1), gaya hidup (X2), pembelajaran di perguruan tinggi (X3) secara parsial mempunyai pengaruh yang signifikan terhadap anggaran berbasis kinerja $(\mathrm{Y})$. Hasil pengujian uji t pada penelitian ini dapat dilihat pada tabel 3 di bawah ini:

Tabel 3. Hasil Uji T

\begin{tabular}{lrrrc}
\hline \multicolumn{1}{c}{ Variabel } & Thitung & T tabel & Signifikansi & Keputusan \\
\hline $\begin{array}{l}\text { Pendidikan Pengelolaan } \\
\text { Keuangan Keluarga }\left(\mathrm{X}_{1}\right)\end{array}$ & 2,789 & 1,65597 & 0,000 & Hipotesis diterima \\
Gaya Hidup $\left(\mathrm{X}_{2}\right)$ & 3,717 & 1,65597 & 0,000 & Hipotesis diterima \\
Pembelajaran Di Perguruan & 2,035 & 1,65597 & 0,000 & Hipotesis diterima \\
Tinggi $\left(\mathrm{X}_{3}\right)$ & & & & \\
\hline
\end{tabular}

Nilai koefisien determinasi yang ditunjukkan dengan R Square sebesar 0.879, yaitu sebesar 87.9 \% dari literasi keuangan dapat dijelaskan oleh variasi dari pendidkan pengelolaan keuangan pribadi, gaya hidup, dan pembelajaran di perguruan tinggi 
sedangkan sisanya sebesar $12.1 \%$ diterangkan oleh variabel lain. Hasil analisis koefisien determinasi dapat dilihat pada tabel 4 :

Tabel 4. Koefisien Determinasi

\begin{tabular}{ccccc}
\hline Model & $\mathrm{R}$ & R Square & $\begin{array}{c}\text { Adjusted } \mathrm{R} \\
\text { Square }\end{array}$ & $\begin{array}{c}\text { Std.Error of } \\
\text { the Estimate }\end{array}$ \\
\hline 1 & $.873(\mathrm{a})$ & .879 & .879 & .120 \\
\hline
\end{tabular}

Pengaruh Pendidikan Pengelolaan Keuangan Keluarga terhadap Literasi Keuangan

Penelitian ini membuktikan bahwa pendidikan keuangan keluarga terbukti berpengaruh terhadap literasi keuangan. Temuan ini sejalan dengan hasil penelitian sebelumnya yang dilakukan oleh Jorgensen (2007) yang menyatakan bahwa siswa yang belajar banyak tentang mengelola keuangan pada orang tuanya memiliki pengetahuan dan sikap keuangan yang lebih tinggi daripada siswa yang tidak belajar tentang mengelola keuangan pada orang tuanya. Penelitian yang dilakukan oleh Cude et. al. (2006) menyatakan bahwa orang tua memainkan peranan yang sangat penting dalam proses sosialisasi keuangan anak-anak mereka. Selain itu, bahwa diskusi secara langsung dengan keluarga mengenai pengelolaan uang akan meningkatkan pengetahuan dan pembentukan sikap, nilai dan perilaku anak-anak (Jorgensen, 2007). Dengan adanya pendidikan pengelolaan keuangan keluarga, pengalaman-pengalaman mahasiswa menjadi bermakna sehingga berkontribusi dalam meningkatkan pengetahuan dasar keuangan mahasiswa. Dengan adanya penanaman sikap, keyakinan dan nilai-nilai pada anak, maka akan mempengaruhi sikap anak terhadap uang. Misalnya mahasiswa yang memiliki pendidikan pengeloaan keuangan yang tinggi tidak akan bersikap boros dan mempunyai penilaian bahwa kesejahteraan keuangan itu sangat penting.

\section{Pengaruh Gaya Hidup terhadap Literasi Keuangan}

Penelitian ini membuktikan bahwa gaya hidup terbukti berpengaruh terhadap literasi keuangan. Dengan gaya hidup yang semakin tinggi, makin besar kesempatan mahasiswa untuk memperoleh pengalaman belajar dalam kehidupan yang berkaitan dengan aspek keuangan (Myers, 2015:5). Hasil penelitian yang dilakukan oleh Lusardi et al. (2010) dan Fowdar (2007) menemukan bahwa gaya hidup berpengaruh terhadap tingkat literasi finansial anak. Secara teori, orang tua yang memiliki pendapatan yang tinggi dapat memfasilitasi anaknya untuk menabung, dan sebagainya. Mahasiswa mempunyai kesempatan yang lebih luas untuk mengembangkan bermacam-macam kecakapan yang tidak dapat dia perkembangkan apabila tidak ada alat-alatnya. Pengembangan literasi finansial sangat terkait dengan aktivitas yang dilakukan seseorang yang berhubungan dengan penggunaan uang. Gaya Hidup mempunyai pengaruh terhadap tingkah laku dan pengalaman anak-anaknya. Pengalaman dalam kehidupan ekonomi sehari-hari khususnya dalam hal keuangan memberikan makna yang berarti bagi perubahan sikap mahasiswa tentang keuangan. Mahasiswa dengan gaya hidup tinggi, dapat memiliki sikap bahwa mereka dapat memperoleh uang dengan mudah dan mereka dapat memiliki apapun yang mereka inginkan, sehingga mahasiswa memiliki pengalaman dan mampu menerapkanhidup hemat dan lebih berhati-hati dalam masalah keuangan. 


\section{Pengaruh Pembelajaran Di Perguruan Tinggi terhadap Literasi Keuangan}

Penelitian ini membuktikan bahwa pembelajaran di perguruan tinggi berpengaruh terhadap literasi keuangan. Temuan ini searah dengan hasil-hasil penelitian terdahulu yang menyatakan bahwa pembelajaran keuangan berpengaruh positif terhadap literasi keuangan mahasiswa. Seperti diungkap oleh Lutfi \& Iramani (2008) pendidikan manajemen keuangan secara signifikan berpengaruh terhadap literasi finansial mahasiswa.

Penelitian Gutter \& Garrison (2008) menemukan bahwa pendidikan keuangan berpengaruh positif terhadap pengetahuan keuangan. Dalam penelitian ini proses pembelajaran manajemen keuangan dan hukum komersial dinilai cukup baik, dan proses pembelajaran pengantar akuntansi dinilai baik. Maka dapat dipahami jika dengan mendapatkan pembelajaran manajemen keuangan, hukum komersial dan pengantar akuntansi, dapat meningkatkan literasi keuangan mahasiswa.

Temuan ini searah dengan penelitian Haryono (2008) yang menyatakan bahwa kualitas proses pembelajaran di sekolah berpengaruh positif terhadap rasionalitas ekonomi dan moralitas ekonomi siswa. Demikian juga penelitian yang dilakukan oleh Gutter \& Garrison (2008) menyatakan bahwa pendidikan keuangan berpengaruh positif signifikan terhadap sikap keuangan. Gutter \& Garrison (2008) juga menyatakan bahwa program keuangan pribadi memiliki dampak positif pada tingkat literasi finansial dan tingkat self efficacy.

Pembelajaran di perguruan tinggi terkait dengan pembelajaran keuangan yang diberikan di jurusan akuntansi meliputi mata kuliah manajemen keuangan, penganggaran, dan pengantar akuntansi. Mata kuliah tersebut mampu memberikan pengetahuan terhadap mahasiswa mengenai pengelolaan keuangan pribadi, pencatatan transaksi keuangan, perencanaan keuangan pribadi masa kini dan masa yang akan datang, jenis-jenis investasi di lembaga keuangan, cara berinvestasi, risiko dan keuntungan berinvestasi. Disamping materi keuangan, pembelajaran juga terkait dengan proses dan penilaian. Melalui berbagai metode pengajaran, media, dan sumber belajar yang sesuai kompetensi mampu memberikan bekal kepada mahasiswa untuk memiliki keahlian di bidang keuangan, sehingga mahasiswa siap dan mampu menghadapi kehidupan saat ini maupun masa depan yang semakin kompleks.

\section{KESIMPULAN DAN SARAN}

Berdasarkan pembahasan hasil penelitian, maka dapat diambil kesimpulan bahwa: (1) Secara simultan pendidikan pengelolaan keuangan keluarga, gaya hidup, dan pembelajaran di perguruan tinggi berpengaruh terhadap literasi keuangan mahasiswa jurusan Akuntansi Politeknik Negeri Malang (2) Secara parsial pendidikan pengelolaan keuangan keluarga, gaya hidup, dan pembelajaran di perguruan tinggi berpengaruh terhadap literasi keuangan mahasiswa jurusan Akuntansi Politeknik Negeri Malang.

Penyempurnaan penerapan literasi keuangan disampaikan beberapa saran yaitu: (1) Bagi Politeknik Negeri Malang dapat memasukkan literasi keuangan sebagai mata kuliah wajib kepada mahasiswa (2) Bagi peneliti selanjutnya masih ada beberapa faktor yang diduga dapat mempengaruhi perilaku pengelolaan keuangan pribadi mahasiswa namun belum dapat dimasukkan oleh peneliti, oleh karena itu disarankan bagi peneliti 
selanjutnya untuk menambah variabel lain seperti kecerdasan emosional, kecerdasan spiritual, pendapatan orang tua, teman sebaya, sikap terhadap uang, dan lain-lain. Peneliti selanjutnya dapat memilih variabel intervening literasi keuangan untuk pengembangan penelitian.

\section{TINJAUAN PUSTAKA}

Andreou, Panayiotis \& Philip, Dennis. (2018). Financial Knowledge Among University Students and Implications for Personal Debt and Fraudulent Investments. SSRN Electronic Journal, 1-27.

Bruhn, Miriam \& Leão, Luciana \& Legovini, Arianna \& Marchetti, Rogelio \& Zia, Bilal. (2016). The Impact of High School Financial Education: Evidence from a LargeScale Evaluation in Brazil. American Economic Journal: Applied Economics. 8. 256295.

Chen, H., \& Volpe, R. P (1998). An analysis of personal financial literacy among college students. Financial Services Review, 7(2), 107-128.

Cude, Brenda \& Lawrence, Frances \& Lyons, Angela. (2006). College students and financial literacy: What they know and what we need to learn. Eastern Family Economics and Resource Management Association Conference Proceedings, 102-109, February 23-25, 2006 in Knoxville Tennessee.

Fowdar. (2007). Financial Literacy: Evidence from Mauritius. Final Report: Mauritius Research Council, 17-28.

Gutter, M.S. \& Garrison, S. (2008). Perceived norms, financial education, and college student credit card behavior. Journal of Consumer Education, 24, 73-88.

Haryono, A. (2008). Pengaruh Sistem Pembelajaran dan Status Soisal Ekonomi Terhadap Economic Literacy Siswa SMA di Kota Malang. Disertasi tidak diterbitkan. Malang: PPs UM.

Johnson, Elizabeth and Sherraden, Margaret S. (2007) "From Financial Literacy to Financial Capability Among Youth," The Journal of Sociology E Social Welfare: Vol. 34 : Iss. 3 , Article 7.

Jorgensen, B.L. (2007). Financial Literacy of College Student: Parental and Peer Influences. Thesis Master of Sains in Human Development. Virginia.

Kaiser, Tim and Lukas Menkhoff. (2017). Does Financial Education Impact Financial Literacy and Financial Behavior, and If So, When?. The World Bank Economic Review, 31(3), 2017, 611-630.

Kapoor, J.R., L.R. Dlabay, dan Hughes, R.J. (2015). Personal Finance, 5th edition. New York: Mc Graw Hill.

Kotler, Philip dan Gary Armstrong. (2018). Principles of Marketing, 17th edition. United Kingdom: Pearson Education.

Lutfi \& Iramani. (2008). Financial Literacy Among University Student and Its Implications to The Teaching Method. Conference Proceedings 8th annual SEAAIR Conference, 401-408, 4-6 November 2008 di STIE Perbanas Surabaya. 
Lusardi, A., and O.S. Mitchell. (2007). “Baby Boomer Retirement Security: The Roles of Planning, Financial Literacy, and Housing Wealth." Journal of Monetary Economics 54 (1): 205-24.

Lusardi, Annamaria, Olivia S. Mitchell, and Vilsa Curto. (2010). Financial Literacy among the Young. Journal of Consumer Affairs, 44 (2): 358-380.

Lusardi, A dan O.S. Mitchell. (2014). The Economic Importance of Financial Literacy: Theory and Evidence. Journal of Economic Literature 2014, 52(1), 5-44.

Mundir, Abdillah. (2018). Penerapan Pendidikan Finansial Pada Anak Usia Sekolah. Journal AL-MUDARRIS (1). 108-120.

Myers, D. G. (2015). Exploring social psychology, 7th Edition. New York: McGraw-Hill Education.

Sugiyono. (2017). Metode Penelitian Bisnis Pendekatan Kuantitatif, Kualitatif, Kombinasi, dan RED. Bandung: Alfabeta.

Sumarwan, Ujang. (2014). Perilaku Konsumen: Teori dan Penerapannya dalam Pemasaran. Bogor: Ghalia Indah.

Trianto. (2015). Mendesain Model Pembelajaran Inovatif progresif. Jakarta: Kencana Prenada Media Grup.

Wahyono, H. (2001). Pengaruh Perilaku Ekonomi Kepala Keluarga terhadap Intensitas Pendidikan Ekonomi di Lingkungan Keluarga. Disertasi tidak diterbitkan. Malang:PPs UM.

Widayati, Irin. (2012). Faktor-Faktor yang Mempengaruhi Literasi Finansial Mahasiswa Fakultas Ekonomi dan Bisnis Universitas Brawijaya. ASSET: Jurnal Akuntansi dan Pendidikan (1) :89-99. 